\title{
Biogenic amine producing bacteria associated with three different commercially fermented beverages in Botswana
}

\author{
Maitshwarelo Ignatius Matsheka*, Clement Chedza Magwamba, Sisai Mpuchane and \\ Berhanu Abegaz Gashe
}

Department of Biological Sciences, University of Botswana, Private Bag UB00704 Gaborone, Botswana.

Accepted 2 January, 2013

\begin{abstract}
The microbial quality and predominant bacterial groups of three fermented beverages was investigated. The bacteria associated with sorghum beer, sour milk (madila/amasi) and sour maize beverage (mageu/mahewu) were determined using standard microbiological techniques. The predominant microorganisms were screened for the production of four biogenic amines using decarboxylase broth. Sorghum beer had the highest bacterial counts with sour maize beverage having the least bacterial counts. Hafnia alvei isolated from sour milk was found to be a major histamine and putrescine producer with 21.2 and $17.56 \mathrm{mg} / 100 \mathrm{ml}$ respectively. On the other hand, the most important cadaverine producers were Pantoea citrea and Hafnia alvei with 19.27 and $18.75 \mathrm{mg} / 100 \mathrm{ml}$ respectively. Enterococcus faecium and Enterococcus faecalis isolated from sour milk were found to be prolific tyramine producers with 35.5 and $20.07 \mathrm{mg} / 100 \mathrm{ml}$ respectively. The Bacillus species isolated from all fermented food products were found to be weak histamine producers. The study also revealed that production of biogenic amines was not a widely distributed property among the lactic acid bacteria as previously documented for other fermented food products. Based on the results, it was concluded that sour maize beverage was the safest fermented food product in terms of the microbial quality and presence of biogenic amine producing bacteria.
\end{abstract}

Key words: Biogenic amines, biogenic acid producing bacteria, fermented beverages, decarboxylase activity, histamine, lactic acid bacteria.

\section{INTRODUCTION}

Fermented foods are major dietary constituents in numerous developing countries in Africa primarily because of their longer keeping quality under ambient conditions, and also for their safety and traditional, organoleptic acceptability (Holzapfel, 2002; McMaster et al., 2005). There are several traditional fermented foods and beverages that are produced at household level in Botswana and in the southern African region as a whole. These include non-alcoholic cereal-based beverages, sour maize beverage (known as mageu/mahewu),

${ }^{*}$ Corresponding author. E-mail: matsheka@mopipi.ub.bw. Tel: 267-355-2607. Fax: 267-318-5097 fermented maize/sorghum porridges (ting), fermented milk (madila) and alcoholic beverages from sorghum or millet malt (bojalwa jwa setswana). Sorghum beer, sour maize beverage (mageu/mahewu) and sour milk (madila/amasi) are some of the commonly consumed traditional fermented foods that have since been commercialized and are currently easily accessible to the urban and rural market.

Sour maize beverage (mageu/mahewu) is a popular fermented non-alcoholic beverage that is readily available on food retail stores in Botswana and South Africa. Traditionally sour maize beverage was produced by the spontaneous fermentation of leftover maize meal porridge. Water is used to macerate the maize meal into a thin gruel and small quantities of wheat flour or 
sorghum malt is blended in to provide the microbial flora to initiate the fermentation process (Gadaga et al., 1999; Holzapfel and Taljaard, 2004). Fermentation is carried out by predominantly Lactic acid bacteria at ambient temperature to yield the characteristic sour taste that is synonymous with the product. Industrial production has seen the use of pure starter cultures such as Lactobacillus brevis and Lactobacillus bulgaricus var delbrueckii in the fermentation process (Holzapfel and Taljaard, 2004; McMaster et al., 2005). The product then is pasteurized to extend the shelf life to 21 days when refrigerated.

Sour milk is traditionally produced by the spontaneous fermentation of raw milk from cattle (Gran et al., 2003). This traditional preparatory method is still widely employed in rural areas of Botswana, South Africa and Zimbabwe (Gadaga et al., 1999; Beukes et al., 2001). Milk is kept in traditional storage vessels such as clay pots and calabashes. Fermentation is carried out over a period of 1 to 3 days by random microbial flora present in the milk, vessels used for fermentation and the environment. After coagulation the whey is drained from the vessel to leave the thick curd which is topped up daily with excess milk from the household, with continued drainage of the whey (Beukes et al., 2001; Gran et al., 2003). Commercial production has seen the introduction of starter cultures with Lactococcus lactis subsp diacetylactis and $L$. lactis subsp cremoris being the strains of choice in industry (Beukes et al., 2001).

Sorghum beer is an opaque beer with a pinkish-brown tinge and a thicker consistency than the conventional beers due to the suspended solids derived from ingredients used in the brewing process. Although brewers might employ slight variations in the industrial production, maize meal or sorghum meal is used as the main form of starch and the malt is primarily derived from sorghum or millet. The beer has a distinct sour taste due to subsequent fermentation by Lactic acid bacteria inherent in the grain used as raw material. Sorghum beer is served while actively fermenting. Industrial production of a popular brand known as Chibuku is expansively covered in the article by Kutyauripo et al. (2009).

Microorganisms play an integral role in acquiring the desired taste in fermented food products. However, contamination by undesirable non-pathogenic and pathogenic microorganisms can occur if good hygienic and manufacturing practices are not implemented during the production process. Apart from affecting the sanitary quality, unwittingly, these microorganisms and some of the microorganisms used as naturally mixed starter cultures may produce toxins such as biogenic amines when the conditions are conducive for their formation. Biogenic amines are renowned for causing adverse health effects when consumed in excessive quantities. They include Histamine and tyramine, which are the main causes of numerous cases of food intoxication; other amines such as putrescine, cadaverine, and phenylethy- lamine are also important because they may intensify the undesirable effects of histamine (Stratton et al., 1991).

In a study that we have previously published, we reported the detection and quantification of four biogenic amines in sorghum beer, sour milk (madila, amasi) and sour maize beverage (mageu/mahewu) (Magwamba et al., 2010). In that study, putrescine was found to be the most common biogenic amine in sorghum beer and sour milk. It occurred in approximately $60 \%$ of the samples. Seventy percent of the sour maize beverage samples had some amount of cadaverine. Although in that study most of the samples in all the three categories of fermented beverages had biogenic amines concentrations all were within acceptable limits. However, one sorghum beer sample had a histamine content above the limit approved by the US Food and Drug Administration (FDA 1992). The current study is a follow up to the investigation and reports on the bacterial groups isolated from the fermented products and their capacity to produce biogenic amines. The study aims to add to the existing knowledge base of biogenic amine producing bacteria. Such a data base can be used to advise the beverage fermentation industry on appropriate strains that can be used as safe starter cultures.

\section{MATERIALS AND METHODS}

\section{Sample numbers and sources}

Seventy nine (79) sour maize beverage (mageu/mahewu), eighty four (84) sour milk (madila/amasi) and eighty seven (87) samples of commercial sorghum beer samples were procured from randomly selected retail markets in Gaborone from May 2007 through September 2008. Samples were transported to the laboratory in an ice cooled box and analyzed within $4 \mathrm{~h}$.

\section{Bacteriological analysis}

For isolation and enumeration of bacterial groups, serial dilutions were performed in $0.1 \%(\mathrm{w} / \mathrm{v})$ peptone water (CM9 Oxoid, Basingstoke, UK) as deemed necessary. All plates with $30-300$ colony forming units after incubation were recorded as recommended in FAO Food and Nutrition paper. 14/4 Rev. 1 (Andrew, 1992).

\section{Total mesophilic and psychrotrophic bacterial counts}

To determine the extent of quality deterioration, total aerobic mesophilic bacterial counts and psychrotrophic bacterial counts were performed by the pour plate method using plate count agar (PCA) (CM325 Oxoid, Basingstoke, UK) as described by Trytinopoulou et al. (2002) and Biaxias-Nogueras et al. (2005). Optimal incubation temperatures for mesophilic and psychrotrphic bacteria were at $30^{\circ} \mathrm{C}$ and $10^{\circ} \mathrm{C}$ for $48 \mathrm{~h}$ and 7 days, respectively.

\section{Endospore forming bacteria}

For endospore enumeration and isolation a 1: 10 food dilution sample was performed in $0.1 \%(\mathrm{w} / \mathrm{v})$ peptone water (Oxoid, CM9, 
Basingstoke, UK) and heated to inactivate vegetative bacterial cells in a water bath for $10 \mathrm{~min}$ at $80^{\circ} \mathrm{C}$-Further serial dilutions were performed using $0.1 \%(\mathrm{w} / \mathrm{v})$ of peptone water when found necessary. Counts of aerobic endospore forming bacteria were performed by the spread plate method on plate count agar (Oxoid, CM325) and counts for anaerobic endospore forming bacteria were performed on plate count agar (Oxoid, CM325) using the pour plate method. Plates were incubated anaerobically at $30^{\circ} \mathrm{C}$ for $48 \mathrm{~h}$ in an anaerobic jar with a $\mathrm{H}_{2}+\mathrm{CO}_{2}$ generating kit (Oxoid, BR38).

After evaluation of colonies by spore staining, suspect Bacillus species were subjected to the following tests to demonstrate proteolytic and lypolytic activity: PCA supplemented with $0.5 \%$ casein and gelatin was used to demonstrate proteolytic activity and lipolytic activity was demonstrated by using PCA supplemented with $0.5 \%$ tributyrin. Growth at different temperatures and concentrations of $\mathrm{NaCl}$ was also determined. Utilization of citrate, reduction of nitrate and production of acid and gas from glucose was determined using standard microbial assessment methods.

Gram positive, catalase negative, endospore forming bacilli, suspected to be Clostridium species were subjected to the following tests; Saccharolytic and lipolytic activities of isolates were determined using PCA supplemented with $0.5 \%$ starch and tributyrin, respectively. Reduction of nitrate using nitrate broth and production of acid from inositol, lactose, mannose, sorbitol and sucrose were additional tests that were carried out. Based on the results obtained above, the Bergey's Manual of Systematic Bacteriology (Sneath et al., 1986) was used to identify the isolates to species level.

\section{Lactic acid bacteria counts}

Counts of lactic acid bacteria were performed by the pour plate count method on deMan Rogosa Sharpe (MRS) agar (Oxoid, CM361) as described by Pons-Sanchez-Cascado et al. (2005) and incubated anaerobically at $30^{\circ} \mathrm{C}$ for $48 \mathrm{~h}$ in an anaerobic jar with a $\mathrm{H}_{2}+\mathrm{CO}_{2}$ generating kit (Oxoid, BR38).

The presumptive Gram positive, non-spore forming and catalase negative lactic acid bacteria (LAB) were further subjected to phenotypic tests as described by Holzapfel and Schillinger (1992), Axelsson (1993), Wood and Holzapfel (1995) and Leisner et al. (2000). In addition to the above tests, all Gram positive cocci isolates were streaked on Bile Aesculin Agar (Oxoid, CM888). The presumptive Streptococcus species which produced a dark brown/ black complex on the agar were further characterized using the API 20 Strep (BioMerieux, France) galleries. API $50 \mathrm{CHL}$ galleries (BioMerieux S.A., Marcy-l'Etoile, France) were also used to identify other LAB to species level.

\section{Enteric bacterial counts}

Counts of enteric bacteria were performed using violet red bile glucose agar (Oxoid, CM485) as described by Pons-SanchezCascado et al. (2005). Enterobacteriaceae-like Gram-negative, oxidase-negative, and catalase-positive isolates were tested for formation of gas from glucose, and fermentation of trehalose using standard tests. Fermentative isolates were characterized with API 20E (BioMerieux, France) galleries.

\section{Pseudomonas spp. counts}

Gram negative oxidase-positive bacteria suspected to be Pseudomonas species were streaked on Pseudomonas Agar Base (Oxoid, CM 559). The isolates were tested for liquefaction of gelatin, production of acid from maltose, production of indole from tryptophane, and fluorescence on King's B agar as described by
Palleroni (1984) and Tryfinopoulou et al. (2002). API 20E (BioMerieux, France) galleries were used to identify the Pseudomonas species.

\section{Gram-positive catalase-positive coccal counts}

Counts of Gram-positive catalase-positive cocci were performed on plates of mannitol salt agar (Oxoid, CM85) as described by PonsSanchez-Cascado et al. (2005). The suspected Staphylococcus aureus isolates were streaked on Baird-Parker agar (Oxoid, CM275) and characteristic jet-black colonies were subjected to standard biochemical tests for the anaerobic utilization of glucose and mannitol, coagulase test and lysostaphin sensitivity.

\section{Confirmation of the identity of isolates to species level}

In addition to the above physiological and biochemical tests, the Biolog Metabolic Fingerprinting (Biolog Inc., Hayward, California.) was used to confirm the identity of Streptococcus, Enterobacteriaceae, Staphylococcus, Pseudomonas, Bacillus and some members of the Lactic acid bacteria to species level.

\section{Screening of identified microorganisms for decarboxylase activity}

Strains identified to species level were prepared for testing by subculturing in nutrient broth (NB CM3, Oxoid, Basingstoke, UK) supplemented with $0.4 \%$ each of the amino acids histidine, tyrosine, lysine, or ornithine and incubated at $25^{\circ} \mathrm{C}$ for $48 \mathrm{~h}$ (da Silva et al., 2002). A loop of each culture was spread on the decarboxylation agars which were then incubated at $25^{\circ} \mathrm{C}$ for $24-48 \mathrm{~h}$. All strains were incubated aerobically except $\mathrm{LAB}$ and Clostridium species which were incubated anaerobically in an anaerobic jar with a $\mathrm{H}_{2}+\mathrm{CO}_{2}$ generating kit (Oxoid, BR38). A purple halo was interpreted as positive for amine production on both media. The exception however, was of the decarboxylation media containing tyrosine because it produced a clear area surrounding the colonies indicating a positive reaction, as observed in other studies, such as that proposed by Joosten and Northholt (1989).

Medium used for preliminary screening of decarboxylating strains was prepared as described by Niven et al. (1981). Additionally, the LAB-specific decarboxylation agar proposed by Maijala (1993), a modified version of the medium described by Joosten and Northolt (1989), was used to detect decarboxylating LAB strains. Both media were autoclaved for $10 \mathrm{~min}$ at $121^{\circ} \mathrm{C}$ to avoid excessive hydrolysis of the agar at low $\mathrm{pH}$. The decarboxylation agar proposed by Maijala (1993) had Tween-80 $0.5 \mathrm{~g} / \mathrm{L}, \mathrm{MgSO}_{4} 0.02 \mathrm{~g} / \mathrm{L}$, $\mathrm{MnSO}_{4} 0.005 \mathrm{~g} / \mathrm{L}$ and $\mathrm{FeSO}_{4} 0.004 \mathrm{~g} / \mathrm{L}$, added to it in order to enhance the growth of $L A B$ strains.

\section{Confirmation of amine forming capacity by HPLC analysis}

Biogenic amine production of the isolates was confirmed using decarboxylase broth according to the method developed by BoverCid and Holzapfel (1999). The decarboxylase broth for LAB was prepared as proposed by Maijala (1993) without agar while that for other microorganisms was prepared as per Niven et al. (1981) description without any agar. Strains were prepared for testing using the method of da Silva (2002). The positive reactions were recorded when a purple color occurred in the decaboxylase broth. $A$ simultaneous inoculation of the strain on decarboxylase broth without an amino acid precursor was performed to eliminate false positive reactions due to formation of other alkaline compounds. Two randomly selected positive broth tubes for each bacterium 
Table 1. Average bacterial counts and biogenic amine content in sorghum beer, sour milk and sour maize.

\begin{tabular}{|c|c|c|c|c|c|c|c|c|c|c|c|}
\hline \multirow{2}{*}{ Food type } & \multicolumn{7}{|c|}{ Average bacterial counts $\log _{10}(\mathrm{CFU} / \mathrm{ml})$} & \multicolumn{4}{|c|}{${ }^{\mathrm{a}}$ Mean biogenic amine $(\mathrm{mg} / 100 \mathrm{ml})$} \\
\hline & TMC & PBC & LAB & ENT & ANA & AER & MIC & HIS & PUT & CAD & TYR \\
\hline Sorghum beer & 8.3 & 5.7 & 7 & 6 & 4.5 & 4 & ND & 0.94 & 1.58 & 1.01 & 2.08 \\
\hline Sour milk & 6.5 & 5.6 & 5.3 & 3.8 & 3.6 & 3.7 & ND & 0.31 & 2.02 & 0.87 & 3.2 \\
\hline Sour maize beverage & ND & ND & ND & ND & ND & ND & ND & 0.01 & 0.12 & 0.09 & 0.002 \\
\hline
\end{tabular}

${ }^{a}$-Mean biogenic amine data published in Magwamba et al. (2010); ND-Not detected TMC- Total mesophilic count; PBC Pyschrotrophic bacterial count; LAB - Lactic Acid Bacteria; ENT- Enterobacteria; ANA - Anaerobic endospore formers; AERaerobic endospore formers; MIC - Micrococcaceae; HIS-histamine; PUT- putrescine; CAD- cadavarine; TYR-tyramine.

were analyzed for biogenic amine production by high-performance liquid chromatography (HPLC) as described previously (Magwamba et al., 2010). An average content of a given biogenic amine was then calculated.

\section{Determination of biogenic amine concentration from the fermented foods}

The concentration of histamine, putrescine, cadaverine and tyramine from sorghum beer, sour milk and sour maize beverage samples was determined as described by Magwamba et al. (2010).

\section{Statistical analysis}

Statistical analyses were performed using the Statistical Package for Social Sciences, SPSS Version 10.0 for windows (SPSS Inc., Chicago, IL, USA). The Pearson correlation was carried out to determine the relationship between specific bacterial counts and biogenic amine concentrations in the each beverage. Value of $P<$ 0.05 was used to indicate significant deviation.

\section{RESULTS}

The microbial quality of three fermented food products was investigated by looking at six parameters, mesophilic bacteria, psychrotrophic bacteria, lactic acid bacteria, enterobacteria, endospore formers, most of which are associated with microbial quality deterioration. Sour maize beverage was found to have the best sanitary quality with the least bacterial counts on all parameters investigated (Table 1). The mean total mesophilic, psychrotrophic and lactic acid bacterial count for sorghum beer and total mesophilic count for sour milk was found to be higher than $5 \log _{10} \mathrm{cfu} / \mathrm{ml}$. The exception was in the case of sorghum beer which had a mean enterobacterial count of $5 \log _{10} \mathrm{cfu} / \mathrm{ml}$.

There was no relationship between the biogenic amine content and various microbial counts investigated except for a positive correlation $(r=0.54)$ between cadaverine concentration and enterobacterial counts in sour milk. There was a weak positive correlation $(r=0.35)$ between mesophilic bacterial counts and cadaverine content in sour milk. However, the low average bacterial counts in sour maize beverage corresponded with low biogenic amine content (Table 1).
The identity of the representative isolates are given in Table 2 and the number of strain isolated across all samples indicated. Therefore, the number of strains isolated per food type gives an approximate figure of the frequency of isolation of the various strains from each product. Bacillus subtilis was the most predominant species isolated across all three fermented food products (Table 2).

Sorghum beer had the highest microbial counts in all microbial quality parameters investigated. Sour milk had the most diverse strains with 21 different bacterial species identified compared to 9 in sorghum beer. Sour maize beverage had the least diversity with 6 bacterial species characterized. Lactic acid bacteria and endospore formers were the only bacterial groups isolated from across all three fermented food products (Table 2). Enteric bacteria were isolated from sour milk and sorghum beer samples, while no isolates were detected in sour maize beverage. A peculiar finding was that all the 64 colonies from the sorghum beer samples were found to be Enterobacter intermedius. One other highlight was that Pseudomonas spp. and members of the Staphylococcus were only isolated from sour milk and not the other fermented foods.

In general, the endospore formers isolated from the fermented food products were weak histamine producers, with the exception of Bacillus subtilis which produced $1.86 \mathrm{mg} / 100 \mathrm{ml}$ of histamine in sorghum beer. A Paenibacillus azotofixans isolate from sorghum beer was the most important putrescine producer at $4.04 \mathrm{mg} / 100$ $\mathrm{ml}$ in decarboxylase broth. The highest cadaverine and tyramine production level was found in Bacillus cereus isolates from sorghum beer with 19.8 and $3.45 \mathrm{mg} / 100 \mathrm{ml}$ respectively (Table 2 ). This was also the only food poisoning pathogen that was isolated from sorghum beer. However, no sample had more than $3 \log _{10} \mathrm{cfu} / \mathrm{ml}$ allowable limit as suggested by the FDA (1992). All the endospore formers isolated from sour maize beverage were found to be weak biogenic amine producers, with less than $1 \mathrm{mg} / 100 \mathrm{ml}$ of a given biogenic amine with the exception of Bacillus subtilis which produced $1.07 \mathrm{mg} /$ $100 \mathrm{ml}$ of histamine in deacarboxylase broth.

Among the members of the enterobacteria Citrobacter freundii was the most predominant species comprising $21 \%$ of the isolates in sour milk. It was also a major 
Table 2. Bacterial isolates from the fermented beverages and the amounts of biogenic amines each produced in decarboxylase broth.

\begin{tabular}{|c|c|c|c|c|c|c|c|c|c|c|c|c|c|c|c|}
\hline \multirow{3}{*}{ Bacteria } & \multicolumn{5}{|c|}{ Sour milk } & \multicolumn{5}{|c|}{ Sorghum beer } & \multicolumn{5}{|c|}{ Sour maize beverage } \\
\hline & \multirow[t]{2}{*}{${ }^{\mathrm{a}}$ No } & \multicolumn{4}{|c|}{$\begin{array}{l}\text { BGA content } \\
(\mathrm{mg} / 100 \mathrm{ml})\end{array}$} & \multirow[t]{2}{*}{ a No } & \multicolumn{4}{|c|}{$\begin{array}{c}\text { BGA content } \\
\text { (mg/100 ml) }\end{array}$} & \multirow[t]{2}{*}{${ }^{\mathrm{a}}$ No } & \multicolumn{4}{|c|}{$\begin{array}{c}\text { BGA content } \\
(\mathrm{mg} / 100 \mathrm{ml})\end{array}$} \\
\hline & & His & Put & Cad & Tyr & & His & Put & Cad & Tyr & & His & Put & Cad & Tyr \\
\hline \multicolumn{16}{|l|}{ Endospore formers } \\
\hline Bacillus subtilis & 72 & ND & 0.20 & 0.27 & 0.11 & 80 & 1.86 & 0.10 & 0.12 & 0.17 & 25 & 1.07 & 0.1 & 0.3 & 0.09 \\
\hline B. thermoglucosidasius & 37 & 1.05 & 0.13 & 0.19 & 0.08 & & & & & & & & & & \\
\hline B. cereus & & & & & & 20 & 1.65 & 0.26 & 19.8 & 3.45 & & & & & \\
\hline B. laevolacticus & 31 & ND & 0.22 & 0.32 & 0.24 & & & & & & & & & & \\
\hline B. halodurans & & & & & & 48 & 1.05 & 0.11 & 0.31 & 1.72 & & & & & \\
\hline B. megaterium & & & & & & & & & & & 22 & 0.72 & 0.18 & 0.22 & 0.14 \\
\hline B. coagulans & & & & & & & & & & & 10 & ND & 0.16 & 0.21 & 0.38 \\
\hline $\begin{array}{l}\text { Paenibacillus } \\
\text { azotofixans }\end{array}$ & & & & & & 39 & ND & 4.04 & 2.36 & 1.88 & & & & & \\
\hline Clostridium spp. & 58 & 0.54 & 0.18 & 0.25 & 0.12 & 67 & 1.11 & 0.23 & 0.42 & 1.01 & 19 & 0.91 & 0.24 & 0.15 & 0.12 \\
\hline \multicolumn{16}{|l|}{ Enterobacteriaceae } \\
\hline $\begin{array}{l}\text { Enterobacter } \\
\text { aerogenes }\end{array}$ & 56 & 1.48 & 8.74 & 1.98 & 2.31 & & & & & & & & & & \\
\hline E. intermedius & & & & & & 64 & ND & 7.50 & ND & 2.02 & & & & & \\
\hline C. freundii & 70 & 2.30 & 11.51 & 0.34 & 3.23 & & & & & & & & & & \\
\hline C. braakii & 65 & ND & 3.44 & 0.21 & 2.86 & & & & & & & & & & \\
\hline Hafnia alvei & 67 & 21.20 & 17.56 & 18.75 & 8.16 & & & & & & & & & & \\
\hline Escherichia coli & 47 & ND & 0.32 & 0.11 & 0.14 & & & & & & & & & & \\
\hline Pantoea citrea & 29 & ND & 6.01 & 19.27 & 5.89 & & & & & & & & & & \\
\hline \multicolumn{16}{|l|}{ Pseudomonads } \\
\hline $\begin{array}{l}\text { Pseudomonas } \\
\text { fluorescens/putida }\end{array}$ & 56 & 18.8 & 11.32 & 15.01 & 1.55 & & & & & & & & & & \\
\hline P.seudomonas spp & 66 & 5.30 & 3.41 & 7.95 & 2.20 & & & & & & & & & & \\
\hline \multicolumn{16}{|l|}{ Staphylococcus } \\
\hline $\begin{array}{l}\text { Staphylococcus } \\
\text { epidermis }\end{array}$ & 52 & 1.16 & 0.48 & 0.22 & 2.02 & & & & & & & & & & \\
\hline S. auricularis & 38 & ND & 0.24 & 0.19 & 0.88 & & & & & & & & & & \\
\hline S. arlettae & 19 & 1.27 & 0.36 & 0.14 & 0.62 & & & & & & & & & & \\
\hline S. aureus & 43 & 0.91 & 1.55 & 0.27 & 2.25 & & & & & & & & & & \\
\hline \multicolumn{16}{|l|}{ Lactic acid bacteria } \\
\hline Enterococcus faecium & 81 & ND & ND & ND & 35.5 & & & & & & & & & & \\
\hline Ent. faecalis & 76 & ND & ND & ND & 20.07 & & & & & & & & & & \\
\hline Ent. gallinarum & 45 & ND & ND & ND & ND & & & & & & & & & & \\
\hline Lactobacillus spp & 37 & ND & ND & ND & ND & 67 & ND & ND & ND & ND & 9 & ND & ND & ND & ND \\
\hline $\begin{array}{l}\text { Carnobacterium } \\
\text { gallinarum }\end{array}$ & 52 & ND & ND & ND & ND & 52 & ND & ND & ND & 21.68 & ND & ND & ND & ND & ND \\
\hline Streptococcus oralis & ND & ND & ND & ND & ND & 35 & 2.34 & 4.20 & 3.81 & 8.64 & ND & ND & ND & ND & ND \\
\hline $\begin{array}{l}\text { Lactococcus } \\
\text { raffinolacticus }\end{array}$ & ND & ND & ND & ND & ND & 29 & ND & ND & ND & ND & ND & ND & ND & ND & ND \\
\hline $\begin{array}{l}\text { Pediococcus } \\
\text { dextrinicus }\end{array}$ & ND & ND & ND & ND & ND & 23 & ND & ND & ND & ND & ND & ND & ND & ND & ND \\
\hline $\begin{array}{l}\text { Leuconostoc } \\
\text { mesenteroides }\end{array}$ & ND & ND & ND & ND & ND & ND & ND & ND & ND & ND & 4 & ND & ND & ND & ND \\
\hline
\end{tabular}

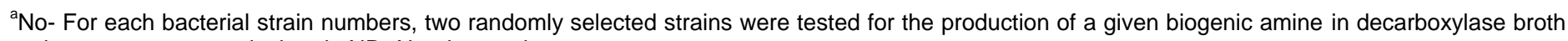
and an average was calculated; ND- Not detected. 
histamine forming bacteria $(2.3 \mathrm{mg} / 100 \mathrm{ml})$ coming only second to Hafnia alvei $(21.2 \mathrm{mg} / 100 \mathrm{ml})$ in decarboxylase broth. The highest putrescine production level was found in Hafnia alvei with $17.56 \mathrm{mg} / 100 \mathrm{ml}$ and the most important cadaverine producers were Pantoea citrea and Hafnia alvei with 19.27 and $18.75 \mathrm{mg} / 100 \mathrm{ml}$ in decaboxylase broth respectively. Hafnia alvei and Pantoea citrea were also found to be the most important tyramine producers with 8.16 and $5.89 \mathrm{mg} / 100 \mathrm{ml}$ in decarboxylase broth respectively. In general, Hafnia alvei was found to be an important biogenic amine producer for sour milk as it produces all four biogenic under investigation in significant quantities. The Pseudomonas fluorescens/putida also isolated from sour milk was found to be a prolific biogenic amine producer, producing significant amounts of all four biogenic amines assayed in the current study (Table 2).

Biogenic amine production was rare among the lactic acid bacteria isolated from all three fermented food products. From the 12 species of lactic acid bacteria identified, only Streptococcus oralis isolated from beer could produce all four biogenic amines under investigation, while only three lactic acid bacteria species were only capable of producing tyramine. These were Enterococcus faecium and Enterococcus faecalis isolates from sour milk and Carnobacterium gallinarum from sorghum beer. All these were all found to be fervent tyramine producer in decarboxylase broth (Table 2).

\section{DISCUSSION}

On assessing the microbial quality of the three fermented beverages, the bacterial load for sorghum beer and total mesophilic count for sour milk was found to be higher than $5 \log _{10} \mathrm{cfu} / \mathrm{ml}$ (FDA, 1992). However, the counts were deemed as acceptable as the lactic acid bacteria play a key role in the fermentation process and could have consequently contributed to the higher total mesophilic and psychrotrophic counts observed. The exception was in the case of sorghum beer which had a mean enterobacterial count of $5 \log _{10} \mathrm{cfu} / \mathrm{ml}$, which is marginally acceptable. This suggests that this beverage is not produced to the desired sanitary standard.

The fact that some Lactic acid bacteria were isolated from across all three fermented food was not unanticipated as lactic acid bacteria are deliberately introduced as starter cultures in most fermented food products. The diversity of lactic acid bacteria isolated in sour milk in the current study was lower than traditionally fermented sour milk documented by Gadaga et al. (1999) and Beukes et al. (2001). This was to be expected as specific starter cultures are used in commercially produced sour milk. However, Lactococcus lactis subsp cremoris, Lactococcus lactis subsp lactis and Lactobacillus plantarum which are usually isolated in traditionally fermented milk and used in commercial preparation of sour milk (Beukes et al., 2001) were not isolated in the current study. Lactobacillus and Leuconostoc species were isolated from sour maize beverage and could constitute deliberately selected starter cultures. Lactococcus lactis subsp lactis is associated with spontaneous fermentation of sour maize beverage (Steinkraus et al., 1993), while commercial production utilizes Lactobacillus delbrueckii (Gardini et al., 2001). However, it was disappointing that a comparative analysis could not be undertaken, as the Lactobacillus isolated in this study could not be identified to species level with absolute certainty due to the lack of sensitivity of the technique.

Sour maize beverage had the best sanitary quality and consequently had the lowest average biogenic amine content when compared to other fermented products. It suggest that sour maize beverage is subjected to a strict pasteurization process and accounts for the insignificant presence of thermoduric endospore formers which was found in this product. However, the presence of certain microbial species that serve as sanitary indicators suggest unsatisfactory hygienic production protocols for sour milk production. Enterococcus faecium and Enterococcus faecalis were the predominant lactic acid bacteria isolated from sour milk. Both species are frequently associated with the gastrointestinal tract of a variety of animals and suggest unsanitary manufacturing practices. This observation is supported by the presence of heat sensitive enterobacteria and Pseudomonas spp. as well as members of the Staphyloccus aureus, which suggests human contact and a lapse in good food handling practice during the manufacturing process.

In general, the endospore formers isolated from the fermented food products were weak histamine producers. These results corresponds well with those of other studies in which members of the genus Bacillus were identified as weak histamine-forming bacteria in fermented fish (Yatsunami and Echigo, 1991) and sufu, a Chinese soybean product (Kung et al., 2007). Bacillus spp. isolated from anchovies have also been found to produce low levels of histamine (Kim et al., 2004). A peculiar finding was that in this study a Bacillus subtilis strain isolated from sour milk was found to be a non histamine producer, whereas the one isolated from sorghum beer was a histamine producer. Previous studies have revealed that the capacity to form amines was strain-dependent, rather than species-dependent (Bover-Cid and Holzafel, 1999; Martin et al., 2006) and this could explain the aberrant observation and differences in biogenic amine production in other report. To our knowledge, this is the first report of decarboxylase activity in Paenibacillus azotofixans

Many members of the family Enterobacteriaceae have been reported to produce considerable levels of histamine (Klausen and Huss, 1987; Halasz et al., 1994). In our study Hafnia akvei was the most prolific biogenic amine producer in sour milk. It is therefore postulated that 
Hafnia alvei was responsible for the bulk of biogenic amine accumulation in sour milk. Strains of Hafnia alvei have been reported to be prolific histamine producers and as such they are considered to be important in the hygiene of fish products (Silla Santos 1998). Hafnia alvei was also found to produce the highest level of putrescine, a finding that has been documented in other studies carried out on meat products (Durlu-Ozkaya et al., 2001). Though there were no justifiable reasons, sour milk was the only food product to have Pseudomonas species. Representative isolates were capable of producing all four biogenic amines.

Studies by Bover-Cid et al. (2001) have reported biogenic amine production among the pseudomonads with Pseudomonas cepacia and Pseudomonas fluorescens producing appreciable amounts of putrescine in sausages.

Staphylococcal isolates were only found in sour milk. All the representative staphylococcal isolates from sour milk were found to be producers of the four biogenic amines under investigation with the exception of Staphylococcus auricularis which was a non-histamine producer. Histamine producing strains of Staphylococcus species have previously been reported by Chen-Chang et al. (2008). This observation has also been documented in earlier studies by Hernandez-Herrero et al. (1999) and Yatsunami and Echigo (1991) who found that most of the Staphylococcus isolates were histamine producers. Putrescine production by Staphylococcus epidermis isolated from salt-dried sardines, have been reported by Lakshmanan et al. (2002) and histidine decarboxylase activity has been detected in Micrococcus and Staphylococcus isolates (Stratton et al., 1991; Yatsunami and Echigo, 1991). Staphylococcus epidermis strain isolated in this study was capable of producing all four biogenic amines. This result correlates well with the findings of Martin et al. (2006), who found that the diamines, putrescine and cadaverine, as well as histamine, were produced simultaneously by several strains identified as $S$. epidermidis. Staphylococcus aureus was the only food poisoning pathogen that was isolated from sour milk, and no sample had more than the $20 \mathrm{cfu} / \mathrm{ml}$ limit suggested by the FDA (1992).

The inability of most Lactic acid bacteria to produce the other three biogenic amines conforms to results obtained in similar studies (Bover-Cid and Holzapfel, 1999; Leuschner et al., 1999; Bover-, 2001). The tyramine producing ability of Enterococcus faecium and Enterococcus faecalis in decarboxylase broth is consistent with data reported by Bover-Cid et al. (2001), Masson et al. (1997), Gardini et al. (2001), Ozogul and Ozugul (2007) and Bonetta et al. (2008). Leuconostoc mesenteroides subsp dextranicum isolated from sour maize beverage was also found to be a non biogenic amine producing bacteria. This confirms the studies by Bover-Cid and Holzapfel (1999) and Straub et al. (1995). However, some strains of Lactococcus and Leuconostoc have been described as tyramine producers (Choudhury et al., 1990; Gonzalez de Llano et al., 1998).

The Enterococcus gallinarum, Lactobacillus spp and Carnobacterium gallinarum isolated from sour milk were non tyramine producers. This is in contrast to the results found by Masson et al. (1997), where strains of Carnobacterium gallinarum were found to produce considerable amounts of tyramine. It is possible that the biogenic amine producing gene(s) might be borne on plasmid(s) and that the strain we isolated might have been cured or lost its plasmid. On the other hand, Carnobacterium gallinarum isolated from sorghum beer was found to be a notorious tyramine producer. Carnobacterium spp. has been previously reported to produce tyramine from tyrosine in laboratory media and chill-stored beef (Edwards et al., 1987; Leisner et al., 1994). Again, strain variability in biogenic amine production was demonstrated. It should be noted that in this study the ability of the strains to produce biogenic amines was only determined in decarboxylase media and not in original food under investigation, so the chemical composition and synergistic interactions with other microbial flora could explain the variability and inconsistency with results from other studies.

The Pearson correlation was used to establish whether there was a relationship between bacterial counts and the presence of biogenic amines. The amount of biogenic amines in foods is used to indicate the extent of food spoilage. In particular, putrescine and cadaverine can be used as indicators of toxicity in fish (Arnold and Brown, 1978; Mietz and Karmas, 1977). However, the same could not be extrapolated to this study. A positive correlation between cadaverine concentration and enterobacterial counts in sour milk was established with the sizeable amount of cadaverine produced by Pantoea citrea and Hafnia alvei enterobacterial species. On the other hand, a weak positive correlation between mesophilic bacterial counts and cadaverine content in sour milk was also evident. The former can be attributed to the sizeable amount of cadaverine produced by Pantoea citrea and Hafnia alvei enterobacterial species while the latter could also be as result of the two enterobacterial strains working in concert with Pseudomonas fluorescens/putida strain which was shown to produce appreciable amounts of cadaverine. Therefore, no particular microbial count parameter can be used as a reliable indicator of biogenic amines as this property seems to be strain specific.

In conclusion, sour milk had the highest diversity of bacteria. It also possessed the highest total average concentration of biogenic amines in line with previous reports by Magwamba et al. (2010). The presence of Enterobacteriaceae, pseudomonads and members of the Staphylococcus in this particular beverage suggests unsanitary production conditions or limitations in the predistribution pasteurization protocol. Lactic acid bacteria were found to produce low levels of biogenic amines with 
the only exception being Streptococcus oralis, Enterococcus faecium and Enterococcus faecalis isolated from sour milk and sorghum beer. These bacteria could possibly have been introduced by contamination as both products were observed to also have members of the family Enterobacteriaceae. Sour maize beverage had the best microbial quality condition and hence the lowest total average of biogenic amines. This data suggests that with careful selection of lactic acid bacteria as starter cultures and the implementation of appropriate hurdle technology to inactivate endospores, fermented foods of good microbial quality and low biogenic amine content are a feasible prospect.

\section{ACKNOWLEDGEMENT}

We are grateful to the Office of Research and Development in the University of Botswana for funding this research.

\section{REFERENCES}

Andrew W (1992). Manual of food quality control 4. Rev.1. Microbiological analysis. FAO of the United Nations. Rome. FAO Food \& Nutrition paper. 14/4 Rev. 1.

Arnold SH, Brown WD (1978). Histamine toxicity from fish products. Adv.Food Res. 24:113-154.

Axelsson LT (1993). Lactic acid bacteria: Classification and physiology. In Lactic Acid Bacteria (Salminen, S. and von Wright, A. eds.) Marcel Dekkers Inc., New York pp. 1-65.

Beukes EM, Bester BH, Mostert JF (2001). The microbiology of South African traditional fermented milks. Int. J. Food Microbiol. 63:189-197.

Biaxias-Nogueras S, Bover-Cid S, Veciana-Nogues T, Marine-Font A, Vidal-Carou MC (2005). Biogenic amine index for freshness evaluation in iced Mediterranean hake (Merluccius merluccius). J.Food Prot. 68(11):2433-2438.

Bonetta S, Bonetta S, Carraro E, Coisson JD, Travaglia F, Arlorio M (2008). Detection of biogenic amine producer bacteria in a typical Italian goat cheese. J.Food Prot. 71(1):205-209.

Bover-Cid S, Holzapfel WH (1999). Improved screening procedure for biogenic amine production by lactic acid bacteria. Int. J. Food Microbiol. 53:33-41.

Bover-Cid S, Izquierdo-Pulido M, Vidal-Carou MC (2001). Effect of the interaction between a low tyramine producing Lactobacillus and proteolytic staphylococci on biogenic amine production during ripening and storage of dry sausage. Int. J. Food Microbiol. 65:113125.

Chen-Chang S, Feng Kung $\mathrm{H}$, Chang Chen H, Saint-Lin C, Hsiang Tsai $Y$ (2008). Determination of histamine and bacterial isolation in swordfish fillets (Xiphias gladius) implicated in a food borne poisoning. Food Control 19(1):16-21.

Choudhury N, Hansen W, Engesser D, Hammes WP, Holzapfel WH (1990). Formation of histamine and tyramine by lactic acid bacteria in decarboxylase assay medium. Lett. Appl. Microbiol. 11:278-281.

Da Silva MV, Pinho O, Ferreira I, Plestilova L, Gibbs PA (2002). Production of histamine and tyramine by bacteria isolated from Portuguese vacuum-packed cold-smoked fish. Food Control 13:457461.

Edwards RA, Dainty RH, Hibbard CM, Ramantanis SV (1987). Amines in fresh beef of normal $\mathrm{pH}$ and the role of bacterias in changes in concentration observed during storage in vacuum packs at chill temperatures. J. Appl. Bacteriol. 63:427-434.

Food and Drug Administration (FDA) (1992). Bacteriological Analytical Manual. $7^{\text {th }}$ Edition. AOAC International 2200 Wilson Blvd, Suite 400,
Arlington, VA.

Gadaga TH, Mutukumira AN, Narvhus JA, Feresu SB (1999). A review of traditional fermented foods and beverages of Zimbabwe. Int. J. Food Microbiol. 53:1-11.

Gardini F, Martuscelli M, Caruso MC, Galgano F, Crudele MA, Favati F Guerzoni, ME, Suzzi G (2001). Effects of $\mathrm{pH}$, temperature and $\mathrm{NaCl}$ concentration on the growth kinetics, proteolytic activity and biogenic amine production of Enterococcus faecalis. Int. J. Food Microbiol. 64:105-117.

Gran HM, Wetlesen A, Mutukumira AN, Rukure G, Narvhus JA (2003). Occurrence of pathogenic bacteria in raw milk, cultured pasteurised milk and naturally soured milk produced at small-scale dairies in Zimbabwe. Food Control 14:539-544.

Halasz A, Barath A, Simon-Sarkadi L, Holzapfed W (1994). Biogenic amines and their production by microorganisms in food-Review. Trends Food Sci. Technol. 5:42-49.

Hernandez-Herrero MM., Roig-Sagues AX, Rodriguez-Jerez JJ, MoraVentura MT (1999). Halotolerant and halophilic histamine forming bacteria isolated during the ripening of salted anchovies. J. Food Prot. 62:509-514.

Holzapfel WH (2002). Appropriate starter culture technologies for small scale fermentation in developing countries. Int. J. Food Microbiol. 75(3):197-212.

Holzapfel WH, Taljaard JL (2004). Industrialization of mageu fermentation South Africa. In Industrialization of indigenous fermented foods, (Steinkraus K.H. ed.), Marcel Dekker, New York pp. 363-407.

Holzapfel WH, Schillinger U (1992). The genus Leuconostoc. In The Prokaryotes, (Balows, A., Truper, H. G., Dwokin, M., Harder, W., Schleifer, K. H. eds.). Springer Veralg, New York. pp.1508-1534.

Joosten HMLJ, Northolt M D (1989). Detection, growth and amineproducing capacity of lactobacilli in cheese. Appl. Environ. Microbiol. 55:2356-2359.

Kim SH, Eun JB, Chen TY, Wei Cl, Clemens RA, An H (2004). Evaluation of histamine and other biogenic amines and bacterial isolation in canned anchovies recalled by the USFDA. J. Food Sci. 69:M557-M162.

Klausen NK, Huss HH (1987). Growth and histamine production by Morganella morganii under various temperature conditions. Int. J. Food Microbiol. 5:147-156.

Kung HF, Lee Y H, Chang SC, Wei Cl, Tsai YH (2007). Histamine contents and histamine-forming bacteria in tofu products in Taiwan. Food Control 18:381-386.

Kutyauripo J, Parawira W, Tinofa S, Kudita I, Ndengu C (2009). Investigation of shelf-life extension of sorghum beer (Chibuku) by removing the second conversion maly. Int. J. Food Microbiol. 129:271-276.

Lakshmanan R, Jeya Shhakila R, Jeyasekaran G (2002). Changes in the halophilic amine forming bacterial flora during salt-drying of sardines (Sardinella gibbosa). Food Res. Int. 35:541-546.

Leisner JJ, Vancanneyt M, Goris J, Christensen H, Rusul G (2000). Description of Paralactobacillus selangorensis gen. Nov., sp. nov., a new lactic acid bacterium isolated from chilibo, a Malaysian food ingredient. Int. J. Syst. Evol. Microbiol. 50:19-24.

Leisner JJ, Millan JC, Huss HH, Larsen LM (1994). Production of histamine and tyramine by lactic acid bacteria isolated from vacuumpacked sugar-salted fish. J. Appl. Bacteriol. 76:417-423.

Leuschner RGK, Kurihara R, Hammes WP (1999). Formation of biogenic amines by proteolytic enterococci during cheese ripening. $\mathrm{J}$. Sci. Food Agric. 79:1141-1144.

Magwamba C, Matsheka MI, Mpuchane S, Gashe BA (2010). Detection and quantification of biogenic amines in fermented food products sold in Botswana. J. Food Prot. 73:1703-1708.

Maijala RL (1993). Formation of histamine and tyramine by some lactic acid bacteria in MRS broth and modified decarboxylation agar. Letters Appl. Microbiol. 17:40-43.

Martin B, Garriga M, Hugas M, Bover-Cid S, Veciana-Nogues MT, Aymerich T (2006). Molecular, technological and safety characterization of Gram positive catalase-positive cocci from slightly fermented sausages. Int. J. Food Microbiol. 107:148-158.

Masson F, Lebert A, Talon R, Montel MC (1997). Effect of physicochemical factors influencing tyramine production by Corynebacterium 
divergens. J. Appl. Microbiol. 83:36-42.

Mcmaster LD, Kokott SA, Reid SJ, Abratt VR (2005). Use of traditional African fermented beverages as delivery vehicles for Bifidobacterium lactis DSM 10140. Int. J. Food Microbiol. 102:231-237.

Mietz JL, Karmas E (1977). Chemical quality index of canned tunas determined by HPLC. J. Food Sci. 42:155-158.

Niven CF, Jeffreg MB, Corlett DA (1981). Differential plating medium for quantitative detection of histamine-producing bacteria. Appl. Environ. Microbiol. 41:321-322.

Ozogul F, Ozogul Y (2007). The ability of biogenic amines and ammonia production by single bacterial cultures. Eur. Food Res. Technol. 225(3-4):384-394.

Palleroni NJ (1984). Gram-negative aerobic rods and cocci, family I. Pseudomonadaceae. In Bergey's Manual of Systematic Bacteriology, (Krieg, N. R. and Holt J. G Eds.), Williams Wilkins, Baltimore pp. 141-219.

Pons-Sanchez CS, Vidal-Carou MC, Marine-Font A, Veciana-Nogues MT (2005). Influence of the freshness grade of raw fish on the formation of volatile and biogenic amines during the manufacture and storage of vinegar-marinated anchovies. J. Agric. Food Chem. 53:8586-8592.

Silla Santos MH (1998). Amino acid decarboxylase capability of microorganisms isolated in Spanish fermented meat products. Int. J. Food Microbiol. 39:227-230.

Sneath PHA, Meir MS, Sharpe ME, Holt JG (1986). Bergey's Manual of Systematic Bacteriology, vol. 2, Baltimore: Williams and Wilkins.
Steinkraus KH, Ayres R, Olek A, Farr D (1993). Biochemistry of Saccharomyces. In Handbook of indigenous fermented foods, (Steinkraus KH ed.), Marcel Dekker, New York pp. 517-519.

Stratton JE, Hutkins RW, Taylor SL (1991). Biogenic amines in cheese and other fermented foods: A review. J. Food Prot. 54:460-470.

Straub BW, Kicherer M, Schilcher SM, Hammes WP (1995). The formation of biogenic amines by fermentation organisms. $Z$. Lebensm. Unters. Forsch. 201:79-82.

Trytinopoulou P, Tsaka Lidou E, Nychas GJE (2002). Characterization of Pseudomonas spp associated with spoilage of gilt-head sea bream stored under various conditions. Appl. Environ. Microbiol. 68(1):6572.

Wood BJB, Holzapfel EH (1995). The genera of lactic acid bacteria, Chapman and Hall, London, UK. p. 398.

Yatsunami K, Echigo T (1991). Isolation of salt tolerant histamineforming bacteria from commercial rice-bran pickled sardine. Bull. Jpn. Soc. Sci. Fish. 57:1723-1728. 